\title{
Linking diatom-diazotroph symbioses to nitrogen cycle perturbations and deep- water anoxia: Insights from Mediterranean sapropel events
}

\author{
Journal Article \\ Author(s): \\ Elling, Felix J.; Hemingway, Jordon D.; Kharbush, Jenan J.; Becker, Kevin W.; Polik, Catherine A.; Pearson, Ann \\ Publication date: \\ 2021-10-01 \\ Permanent link: \\ https://doi.org/10.3929/ethz-b-000501654
}

Rights / license:

Creative Commons Attribution-NonCommercial-NoDerivatives 4.0 International

Originally published in:

Earth and Planetary Science Letters 571, https://doi.org/10.1016/j.epsl.2021.117110 


\section{Linking diatom-diazotroph symbioses to nitrogen cycle perturbations and deep-water anoxia: Insights from Mediterranean sapropel events}

Felix J. Elling ${ }^{\mathrm{a}, *, 1,2}$, Jordon D. Hemingway ${ }^{\mathrm{a}, *, 1,3}$, Jenan J. Kharbush ${ }^{\mathrm{a}, 4}$, Kevin W. Becker ${ }^{\mathrm{b}, 5}$, Catherine A. Polik ${ }^{a, 4}$, Ann Pearson ${ }^{a}$

a Department of Earth and Planetary Sciences, Harvard University, 20 Oxford Street, Cambridge, MA 02138, USA

${ }^{\mathrm{b}}$ Department of Marine Chemistry and Geochemistry, Woods Hole Oceanographic Institution, 266 Woods Hole Road, Woods Hole, MA 02143, USA

\section{A R T I C L E I N F O}

\section{Article history:}

Received 9 December 2020

Received in revised form 4 July 2021

Accepted 8 July 2021

Available online 30 July 2021

Editor: L. Derry

\section{Keywords:}

anammox

anoxia

compound-specific $\delta^{13} \mathrm{C}$

diatom-diazotroph symbioses

$\mathrm{N}_{2}$-fixation

Mediterranean sapropels

\begin{abstract}
A B S T R A C T
Elevated organic matter (OM) export flux promotes marine anoxia, thus increasing carbon sequestration efficiency and decreasing atmospheric carbon dioxide levels. However, the mechanisms that trigger and sustain anoxic events-particularly those associated with nutrient-poor, oligotrophic surface watersremain poorly constrained. Mediterranean Sea sapropels are well-preserved sediments deposited during episodic anoxic events throughout the Plio-Pleistocene; as such, they may provide unique insight into the biogeochemical and ecological drivers of-and responses to-marine anoxia. Using biomarker distributions, we demonstrate that anaerobic ammonium oxidizing (anammox) bacteria and diazotrophic endosymbionts of mat- and/or raft-forming diatoms were both abundant during sapropel events, particularly in the Ionian and Libyan seas. In these sapropels, the carbon isotope compositions of anammox biomarkers directly capture progressive ${ }^{13} \mathrm{C}$-depletion in deep-water dissolved inorganic carbon, indicating sustained carbon sequestration. To explain these observations, we propose a reinforcing feedback whereby initial nutrient and/or circulation perturbations promote fixed nitrogen loss via intensified anammox and heterotrophic denitrification, which in turn favors proliferation of rapidly sinking diatom-diazotroph symbiotic consortia, increases OM burial flux, and sustains anoxia. This mechanism resolves the long-standing conundrum that small and buoyant diazotrophs are apparently associated with high OM export during periods of marine anoxia and oligotrophy.
\end{abstract}

(C) 2021 The Author(s). Published by Elsevier B.V. This is an open access article under the CC BY-NC-ND license (http://creativecommons.org/licenses/by-nc-nd/4.0/).

\section{Introduction}

Marine primary production-the amount of organic matter (OM) produced by photosynthetic organisms in the surface oceanis limited by the supply of nutrients, namely phosphorus and nitrogen (Van Cappellen and Ingall, 1996). Although most OM is recycled near the surface, some is exported to depth where it is aerobically respired. This process consumes dissolved oxygen

\footnotetext{
* Corresponding authors.

E-mail addresses: felix_elling@fas.harvard.edu (F.J. Elling), jordon.hemingway@erdw.ethz.ch (J.D. Hemingway).

1 These authors contributed equally to this work.

2 Current address: Leibniz-Laboratory for Radiometric Dating and Isotope Research, Kiel University, Max-Eyth-Str. 11-13, 24118, Kiel.

3 Current address: Geological Institute, Department of Earth Sciences, ETH Zurich, Sonneggstrasse 5, 8092 Zurich, Switzerland.

4 Current address: Department of Earth and Environmental Sciences, University of Michigan, 428 Church St, Ann Arbor, MI 48109, USA.

5 Current address: Marine Biogeochemistry Division, GEOMAR Helmholtz Centre for Ocean Research Kiel, Düsternbrooker Weg 20, 24105 Kiel, Germany.
}

$\left(\mathrm{O}_{2}\right)$, produces carbon dioxide $\left(\mathrm{CO}_{2}\right)$, and regenerates nutrients that can be returned to the surface via overturning circulation (Kemp and Villareal, 2013; Wright et al., 2012). However, if aerobic respiration outpaces circulation-derived $\mathrm{O}_{2}$ supply, deep waters become anoxic and "fixed" nitrogen species (nitrate, $\mathrm{NO}_{3}^{-}$; nitrite, $\mathrm{NO}_{2}^{-}$; and ammonium, $\mathrm{NH}_{4}^{+}$) become important energy sources for anaerobic microorganisms (Mills and Arrigo, 2010; Wright et al., 2012). Specifically, both heterotrophic denitrification and autotrophic anaerobic ammonium oxidation (anammox) consume fixed nitrogen, produce dinitrogen gas $\left(\mathrm{N}_{2}\right)$, and limit the return of nutrient nitrogen to the surface. Such loss of fixed nitrogen should promote the proliferation of small, photosynthetic, $\mathrm{N}_{2}$ fixing cyanobacteria ("diazotrophs") with high nutrient uptake efficiency and slow sinking rates (Marañón, 2015). This diazotrophic feedback is expected to replenish fixed nitrogen inventories and decrease the rate of OM export, thus providing mechanistic insurance against runaway anoxia.

However, observations of ecosystem response during PlioPleistocene sapropel events in the Mediterranean Sea contrast with these predictions. The sedimentary records of microfossils (Kemp 
et al., 1999; Schrader and Matherne, 1981) and organic biomarkers (Higgins et al., 2010) indicate sustained proliferation of eukaryotic algae during anoxic periods. These observations imply that nutrient-poor (i.e., oligotrophic) surface waters can continue to support elevated export production and the growth of large eukaryotes, sustaining high rates of remineralization at depth and amplifying, rather than dampening, deep-water anoxia (Calvert et al., 1992; Sachs and Repeta, 1999). Resolving this paradox and understanding the connections between both regional and global oxygen, carbon, and nitrogen cycles requires new constraints on the microbiological and biogeochemical mechanisms that promote and sustain anoxia.

To provide insight into nutrient cycling in low-oxygen basins, we measured lipid biomarker abundances and compound-specific stable carbon isotope compositions as well as the elemental and isotopic compositions of bulk OM from sediments deposited in the Eastern Mediterranean Sea during five Plio-Pleistocene sapropel events. By quantifying bacteriohopanepolyols (BHPs) specific to anammox bacteria and heterocyst glycolipids (HGs) specific to diazotrophic cyanobacteria, we provide the first simultaneous assessment of the distribution and types of fixed nitrogen sources and sinks in response to anoxia. To assess spatial variability of the nitrogen cycle during sapropel events, we additionally compile all previously reported biomarker and diatom microfossil data from the literature. Finally, we compare Mediterranean sapropel results to biomarker distributions from open-ocean anoxic events (OAEs)-for example, during the Cretaceous Period-which do not record evidence of elevated anammox activity but rather suggest increased nitrite oxidation. Collectively, these analyses suggest that nutrient regimes during sapropel events resembled those of modern anoxic basins but were fundamentally different from those during OAEs.

\section{Study site}

Today, the Eastern Mediterranean is a well-ventilated, oligotrophic basin characterized by low surface nutrient concentrations, low primary productivity, and organic-poor, calcareous marl sediments (Rohling et al., 2015). However, insolation-driven increases in monsoon intensity and freshwater runoff throughout the Plio-Pleistocene episodically slowed overturning circulation, leading to deep-water anoxia and the deposition of organic-rich "sapropel" sediments. Such events were basin-wide phenomena lasting between 1000 and 10,000 years and yielding 1 to $30 \mathrm{~cm}$ thick sapropel deposits (Rohling et al., 2015; Sachs and Repeta, 1999). Because of their episodic nature and high sediment accumulation rates (Rohling et al., 2015), sapropels are an ideal setting to interrogate biogeochemical cycles during periods of marine anoxia.

Here, we specifically investigate five sapropel events-S4 (onset: 108 ka before present), S5 (128 ka), S7 (197 ka), i-282 (2.947 $\mathrm{Ma})$, and S74 (3.004 Ma)-from two Eastern Mediterranean locations, Ocean Drilling Program Leg 160 sites $964\left(36.26^{\circ} \mathrm{N} ; 17.75^{\circ}\right.$ $\mathrm{E} ; 3658 \mathrm{~m}$ water depth) and $967\left(34.07^{\circ} \mathrm{N} ; 32.73^{\circ} \mathrm{E} ; 2553 \mathrm{~m}\right.$ water depth) (Fig. 1; Table S1). Site 964 is located in the deep, more westerly Ionian Sea and is described by intense seafloor and watercolumn anoxia, including periods of photic-zone euxinia. It experiences minimal freshwater inputs due to its long distance from (paleo-)riverine sources (Rohling et al., 2015). Site 967 is located in the shallower, more easterly Levantine Sea and is expected to receive significant freshwater input during monsoon-driven sapropel events (Rohling et al., 2015). To further assess how these differences influence spatial variability in nitrogen-cycling processes, we additionally compared our results from event S5 to diatom microfossil and biomarker distributions reported in the literature from other coring locations during this event (Bale et al., 2019; Bauersachs et al., 2010; Rush et al., 2019) (Fig. 1).

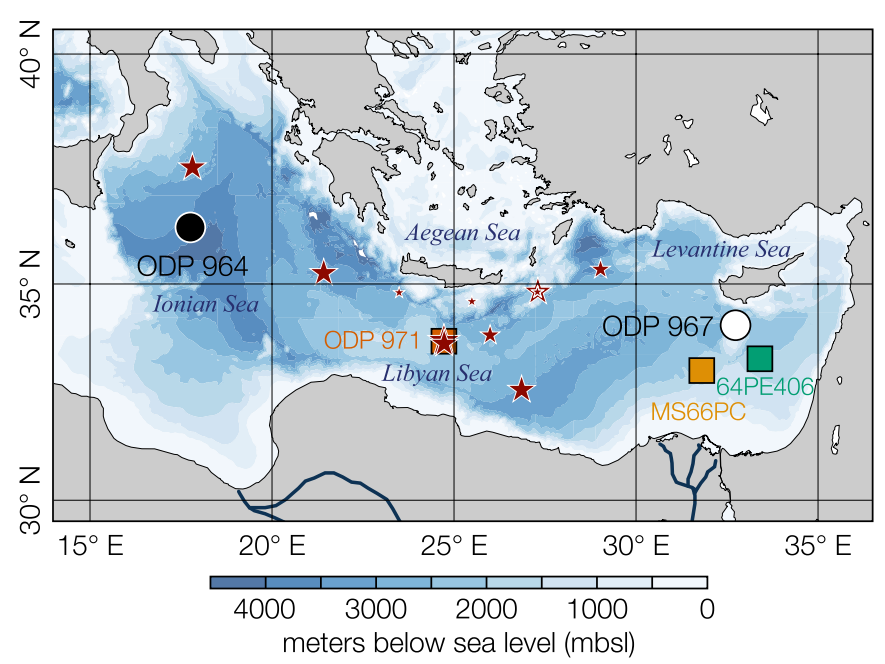

Fig. 1. Map showing eastern Mediterranean Sea sampling sites. Data presented in this study are from ODP leg 160 sites 964 (black circle) and 967 (open circle). Sites in which BHT and/or HG abundances during sapropel S5 have been previously measured (Bale et al., 2019; Rush et al., 2019) are shown as squares (64PE406, turquoise; MS66PC, gold; ODP leg 160 site 971, orange). Red stars indicate sites reported to contain preserved diatom microfossils during sapropel S5; marker sizes are scaled by preservation quality (largest = "excellent", smallest = "poor"; Table S7). Map shading represents bathymetry (colored) or land masses (gray); dark blue lines indicate reconstructed paleo channels of major river inputs during sapropel events (Rohling et al., 2015). (For interpretation of the colors in the figure(s), the reader is referred to the web version of this article.)

\section{Materials and methods}

\subsection{Sample preparation and extraction}

Sediment samples were freeze dried, homogenized by mortar and pestle, and extracted in Teflon vessels using a CEM Mars microwave extraction system in three steps: (i) 1:1 dichloromethane: methanol, (ii) 9:1 dichloromethane:methanol, and (iii) 100\% dichloromethane. The microwave program consisted of (i) $30 \mathrm{~min}$ ramped heating program to $100^{\circ} \mathrm{C}$, (ii) hold at $100^{\circ} \mathrm{C}$ for 20 min, (iii) cool-down for $10 \mathrm{~min}$, after which solvent was decanted and fresh solvent added. The extracted sediment was rinsed three times with dichloromethane until the extract became colorless. The extracts and rinses were combined into a total lipid extract (TLE), dried under $\mathrm{N}_{2}$, and stored at $-20^{\circ} \mathrm{C}$.

Following Pearson et al. (2016), TLE aliquots were separated over pre-combusted $\mathrm{SiO}_{2}$ (130-270 mesh) into five fractions: (i) F1 (100\% $n$-hexane), (ii) F2-5 (10\% ethyl acetate:n-hexane), (iii) F6-8 (25\% ethyl acetate: $n$-hexane), (iv) F8.5 (1:1 ethyl acetate: $n$-hexane), and (iv) F9-10 (100\% ethyl acetate, followed by $100 \%$ methanol). Both BHPs and HGs were contained in F9-10, whereas crenarchaeol was contained in F8.5.

\subsection{Biomarker quantification}

\subsubsection{Bacteriohopanepolyols}

BHPs in dried aliquots of F9-10 were acetylated with 1:1 acetic anhydride:pyridine overnight at room temperature (Hemingway et al., 2018). After derivatization, samples were evaporated to dryness, reconstituted in 30:70 methanol:isopropanol, filtered through $0.45 \mu \mathrm{m}$ pore size syringe-tip PTFE filters, and stored at $-20^{\circ} \mathrm{C}$. Following Kusch et al. (2018), the acetylated fractions were injected into a coupled high-performance liquid chromatography (HPLC)-mass spectrometry system (MS) consisting of an Agilent 1290 series HPLC and an Agilent 6410 triple quadrupole mass spectrometer (QqQ-MS) equipped with an atmospheric-pressure chemical ionization interface run in positive ion mode. Ion source 
and selected reaction monitoring parameters (Table S2) were optimized by infusion of acetylated extracts of Rhodopseudomonas palustris TIE-1 as described by Kusch et al. (2018). BHP abundances are reported semi-quantitatively as peak areas normalized to total organic carbon content (area $\mathrm{gOC}^{-1}$ ) due to a lack of commercially available BHP standards. While ionization depends on BHP functional groups, ionization efficiencies among structural isomers are expected to be identical. Due to potentially larger ion suppression effects for sapropelic samples relative to the organic-lean marls, sapropel BHP concentrations represent minimum estimates (Fig. S1).

\subsubsection{Heterocyst glycolipids}

Heterocyst glycolipids were quantified using positive electrospray ionization (ESI) HPLC-MS on the QqQ-MS system described above. Compounds were separated using a Waters Acquity BEH amide column $(2.1 \times 150 \mathrm{~mm}$ inner diameter, $1.7 \mu \mathrm{m}$ particle size $)$ maintained at $50^{\circ} \mathrm{C}$ and the solvent gradient described by Wörmer et al. (2012). Heterocyst glycolipids were quantified using characteristic multiple reaction monitoring (MRM) transitions (Table S3). Ion source parameters and MRM transitions were optimized by infusion of lipid extracts of the heterocystous cyanobacteria Anabaena cylindrica UTEX 1611 and Nostoc sp. PCC 7120, grown in inorganic nitrogen-free $\mathrm{BG}-11_{0}$ media. Biomass was harvested at stationary phase using centrifugation $(4000 \times g)$. Lipids were extracted using either microwave extraction as described above or following a modified Bligh and Dyer protocol (Sturt et al., 2004). Relative and absolute abundances of heterocyst glycolipids in TLEs derived from microwave and Bligh and Dyer extractions were identical. MRM transitions for heterocyst glycolipids absent from the cultures were optimized using sapropel sediment samples. Linearity of instrument response was determined using a dilution series $(2-500 \times)$ of a sapropel TLE (Fig. S1). To limit the impact of differences in instrument response between $C_{5}$ and $C_{6}$ heterocyst glycolipids, the amounts of TLE injected into the HPLC-MS were adjusted to achieve similar peak areas for all samples. Reported heterocyst glycolipid abundances are semi-quantitative due to a lack of authentic standards.

Identification of heterocyst glycolipids was confirmed using a Thermo Q Exactive Orbitrap high-resolution MS connected to an Agilent 1200 HPLC system. Detection was achieved using positive ion ESI, while scanning an $\mathrm{m} / \mathrm{z}$ range from 100 to 1500 . The mass spectrometer was set to a resolving power of 140,000 (Full Width at Half Maximum at $m / z 200$ ) and to 17,500 for $\mathrm{MS}^{2}$ scans, which resulted in an observed resolution of 75,100 at $\mathrm{m} / \mathrm{z} 875.5505$ of an internal standard (2,4-dinitrophenyl phosphatidylethanolamine diacylglycerol; Avanti Polar Lipids, Inc., Alabaster, AL) (Collins et al., 2016). MS $^{2}$ spectra were obtained in data dependent mode. For each MS full scan, three ions of highest intensity were selected in series using the quadrupole for $\mathrm{MS}^{2}$ fragmentation (4 Da isolation window) with a Stepped Normalized Collision Energy of 20, 50 , and 80. Analytes were separated using reversed phase HPLC on an $\mathrm{C}_{8}$ XBridge column $(2.1 \times 150 \mathrm{~mm}, 5 \mu \mathrm{m}$ particle size, Waters Corp., Milford, MA, USA) as described in Collins et al. (2016). Heterocyst glycolipids were identified by retention time, as well as accurate molecular mass of proposed sum formulas in full scan mode and tandem MS fragment spectra.

\subsection{Biomarker isotopic analyses}

All biomarker and bulk isotope results are reported in delta notation relative to Vienna Pee Dee Belemnite (VPDB; for $\delta^{13} \mathrm{C}$ ) and air (for $\delta^{15} \mathrm{~N}$ ), respectively, with uncertainty reported as $\pm 1 \sigma$ between replicate measurements (after propagating uncertainty from acetate carbon correction in the case of BHPs). The carbon isotopic composition of $\mathrm{CO}_{2}$ (aq) relative to DIC (assuming $\mathrm{T}=15^{\circ} \mathrm{C}$ ) was calculated according to (Mook et al., 1974).

\subsubsection{Bacteriohopanepolyols}

BHP isotopic analysis was performed following Hemingway et al. (2018) using a synthetic sterol internal standard (cholestane3b,5a,6b-triol, $\delta^{13} \mathrm{C}=-28.57 \pm 0.03 \%$ VPDB) to correct for the effect of acetylation on BHP $\delta^{13} \mathrm{C}$ values. Individual acetylated BHPs, as well as the standard, were isolated into separate fractions using an Agilent 1290 Infinity series HPLC coupled to an Agilent 1260 Infinity series fraction collector; multiple injections were performed for each sample and fractions from repeat injections were combined to prepare sufficient compound masses for isotopic analysis. BHP recoveries and purities were assessed by analyzing ca. $5 \%$ of each preparatory fraction using flow injection analysis and QqQMS detection. Complete separation of bacteriohopanetetrol (BHT-I) and its isomer (BHT-II) was verified by analyzing every fraction using the HPLC-MS method described above. Compound-specific $\delta^{13} \mathrm{C}$ values were determined using a Thermo Scientific Trace gas chromatograph (GC) Ultra equipped with a programmable temperature vaporizing inlet and a Zebron ZB-5HT high temperature column (30 m $\times 0.25 \mathrm{~mm}$ inner diameter.; $0.10 \mu \mathrm{m}$ film thickness) and coupled to a Thermo Scientific Delta V Advantage isotope ratio mass spectrometer (IRMS) via a GC Isolink system held at $1000{ }^{\circ} \mathrm{C}$. Resulting ${ }^{13} \mathrm{C} /{ }^{12} \mathrm{C}$ ratios were calibrated against $\mathrm{CO}_{2}$ gas with a known $\delta^{13} \mathrm{C}$ value. All samples were injected at least in triplicate. To monitor instrument performance and apply offset (accuracy) corrections, 10-20 ng of an internal standard with known isotope composition ( $n-C_{38}$ alkane) was co-injected with each sample. $n-C_{38}$ standard long-term accuracy was better than $0.35 \%$ and precision was $\leq 0.30 \%$ o $(n=112)$.

\subsubsection{Crenarchaeol}

Additional crenarchaeol $\delta^{13} \mathrm{C}$ data were generated to expand upon the dataset of Polik et al. (2018). Crenarchaeol was purified from F8.5 by sequential normal phase and reverse-phase HPLC as described previously (Pearson et al., 2016; Polik et al., 2018). Carbon stable isotopic composition of crenarchaeol was analyzed in six replicates using spooling wire microcombustion-IRMS (Pearson et al., 2016). Isotopic compositions were standardized to a $\mathrm{CO}_{2}$ reference gas, the $\mathrm{C}_{46}$-GTGT standard, and a crenarchaeol standard of known isotopic composition. A dilution series of $\mathrm{C}_{46}$-GTGT was used to correct for sample size bias. Purity was assessed by measuring sample (F2) to background (F1) ratios (F2/F1). All reported F2/F1 values were above the threshold of 2 established previously to yield acceptable $\delta^{13} \mathrm{C}$ values of crenarchaeol (Polik et al., 2018).

\subsection{Elemental analysis}

Total nitrogen content (TN) and isotopic composition $\left(\delta^{15} \mathrm{~N}\right)$ of dry, homogenized bulk sediment aliquots were analyzed using a ThermoScientific Flash EA Delta V Plus IRMS. Using the same instrumental setup, total organic carbon (TOC) content and carbon isotopic composition $\left(\delta^{13} \mathrm{C}\right)$ were analyzed on samples acidified in silver capsules, which were wrapped in tin capsules before combustion. Sediment nitrogen and carbon isotope compositions were peak size-corrected and offset-corrected using laboratory and authentic reference standards (glutamic acid: $\delta^{13} \mathrm{C}=-13.90 \%$, $\delta^{15} \mathrm{~N}=-5.90 \%$; tyrosine: $\delta^{13} \mathrm{C}=-24.90 \%, \delta^{15} \mathrm{~N}=-4.96 \%$; USGS40: $\delta^{13} \mathrm{C}=-26.39 \%, \delta^{15} \mathrm{~N}=-4.52 \%$; USGS41a: $\delta^{13} \mathrm{C}=$ $36.55 \%$, $\delta^{15} \mathrm{~N}=47.55 \%$ ).

\subsection{Statistical analyses}

Regressions were calculated using weighted least squares (WLS); this approach assumes zero uncertainty in $x$ values and weights 
each data point by the inverse of the standard deviation of its $y$ value. All data distribution comparisons were calculated using the two-tailed non-parametric Mann-Whitney U test. Reported $p$ values are the probability of falsely rejecting the null hypothesis of zero slope (for regressions) or equal means (for distribution comparisons).

\section{Results \& discussion}

\subsection{Enhanced loss of fixed nitrogen is linked to increased abundance of anammox bacteria}

For all events at all coring locations, total organic carbon (TOC) content increases by $>10$-fold in sapropels relative to marl sediments (Fig. 2a, 3a), indicating elevated primary production, increased preservation efficiency, or both (Calvert et al., 1992; Sachs and Repeta, 1999). In tandem, $\delta^{15} \mathrm{~N}$ values of TN shift from a background near $+5 \%$ in marl sediments to values as low as $-3 \%$ o just before sapropel termination (Fig. 2d, 3b). Such reproducible trends indicate similar carbon- and nitrogen-cycle perturbations occurred throughout the Eastern Mediterranean for each anoxic event, as has been shown previously (Calvert et al., 1992; Higgins et al., 2010; Polik et al., 2018). Although ${ }^{15} \mathrm{~N}$-enriched marl signatures have been suggested to reflect diagenetic isotope fractionation rather than a shift in ${ }^{15} \mathrm{~N}$ signature of the primary nitrogen source (Möbius et al., 2010), such interpretations would require concomitant increases in bulk $\mathrm{C} / \mathrm{N}$ ratios and TOC $\delta^{13} \mathrm{C}$ values due to the preferential remineralization of $\mathrm{N}$-rich and ${ }^{13} \mathrm{C}$ - and ${ }^{15} \mathrm{~N}$-depleted OM. This is not observed within the present samples (Fig. 2b-c), confirming that sapropel vs. marl differences reported here reflect a change in primary $\delta^{15} \mathrm{~N}$ signals (see Supplementary Information for further discussion).

Depletion in ${ }^{15} \mathrm{~N}$ has traditionally been interpreted to reflect increased importance of diazotrophic production, since $\mathrm{N}_{2}$-fixing cyanobacteria produce biomass with $\delta^{15} \mathrm{~N}$ values between -2 and $0 \%$ (Higgins et al., 2011). In contrast, incorporation of pre-formed, ${ }^{15} \mathrm{~N}$-enriched fixed nitrogen (e.g., $\mathrm{NO}_{3}^{-}$) increases bulk $\mathrm{OM} \delta^{15} \mathrm{~N}$ values to $>0 \%$, although the exact composition of pre-formed nitrogen in the Mediterranean Sea is difficult to constrain and likely differed from the canonical open-ocean value of $+5 \%$ (Higgins et al., 2010; Möbius et al., 2010). Nonetheless, positive values are observed for marl horizons, but all sapropel events show near-zero or negative values (Fig. 3b). Such full expression of diazotroph ${ }^{15} \mathrm{~N}$ fractionation during sapropel events implies complete removal of upwelling, pre-formed, and regenerated fixed nitrogen before it can re-enter the photic zone; this result requires concomitant, continuous input of newly fixed nitrogen to surface waters in sufficient quantities to sustain primary production. Importantly, this trend appears to be a basin-wide phenomenon, as evidenced by the identical $\delta^{15} \mathrm{~N}$ evolution during event S5 at all coring locations. Despite this persistent pattern, there is little direct evidence to date that could explain the mechanisms responsible for quantitative loss of regenerated nitrogen.

Our biomarker and bulk sediment data suggest elevated anammox activity associated with these sharp increases in the consumption of fixed nitrogen within the chemocline during sapropel events. Carbon-normalized abundances of bacteriohopanetetrol (BHT-I) and its isomer (BHT-II)-bacterial biomarkers that are commonly produced within modern oceanic anoxic zones (Wakeham et al., 2012) and are preserved on million-year timescales (Hemingway et al., 2018; Rush et al., 2019)-increased by up to three orders of magnitude at both study sites, with the largest increase occurring during Pliocene event S74 at site 967 followed by all events at site 964 (Fig. 2f, 3d). Importantly, such trends cannot simply be explained by enhanced preservation leading to increased overall TOC content; rather, they require a shift toward a BHT-rich source (Fig. S2a). While BHT-I is a generic bacterial biomarker, as evidenced by its ${ }^{13} \mathrm{C}$ composition near that of bulk organic carbon (Fig. 4), BHT-II is likely produced exclusively by autotrophic anammox bacteria (Rush et al., 2014). Strong ${ }^{13} \mathrm{C}$-depletion in BHTII (median $\delta^{13} \mathrm{C}=-47.1 \%, n=27$; Fig. 4), consistent with the Wood-Ljungdahl carbon fixation pathway (Schouten et al., 2004), confirms an anammox bacterial source.

In addition to elevated total BHT concentrations, the fractional abundance of BHT-II $\left[f_{\text {BHT-II }}=\right.$ BHT-II/(BHT-I+BHT-II) $]$ consistently increased from an average of 0.25 before sapropel onset to $>0.5$ within sapropels (Fig. 2h, 3f), reflecting enhanced anammox contribution to the total bacterial community biomass (Fig. S3a). Interestingly, the relative shift is less pronounced at site 964 than at site 967 due to the former also yielding high $f_{\text {BHT-II }}$ values in marl sediments, suggesting more persistent anammox activity despite low total BHT abundances during oligotrophic conditions in the Ionian Sea. In contrast, the shallower, more land-proximal Levantine Sea contains substantially lower $f_{\text {BHT-II }}$ outside of sapropel events, making the relative increase appear larger. Consistent with previous results (Rush et al., 2019), Pliocene events at both study sites display a transient dip in $f_{\text {BHT-II }}$ within the sapropel "core", possibly due to inflow of ventilated deep water (Rohling et al., 2015); however, all Pleistocene events show either stable $f_{\text {BHT-II }}$ values or a peak during core sapropel formation.

These observations suggest overall intensification of a highly reducing nitrogen cycle coupled to vigorous $\mathrm{N}_{2}$-fixation. We additionally observe concomitant orders-of-magnitude increases in the abundance of lipids from aerobic ammonia-oxidizing archaea (i.e., crenarchaeol; Fig. 2e, 3c; Polik et al., 2018), as would be required to supply the nitrite necessary to drive the anammox reaction. Ammonium diffusing from the anoxic zone would have been quantitatively removed by the interplay of anammox bacteria, ammonia-oxidizing archaea and nitrite-oxidizing bacteria occupying their respective redox niches in the deep-to-shallow chemocline, respectively. Although terminal nitrate resulting from these processes could have served as a source of regenerated fixed nitrogen to phytoplankton, the negative $\delta^{15} \mathrm{~N}$ values of bulk OM indicate this source was quantitatively unimportant, either because (i) nitrite oxidation was largely out-competed by the anammox sink, (ii) most nitrate was not recycled into the photic zone but was efficiently consumed by denitrifiers, similar to what is observed in the modern Black Sea (Lam et al., 2007), or (iii) some combination of these effects.

\subsection{Diatom-diazotroph symbiosis supports increased export production}

Efficient removal of fixed nitrogen resulting from the interplay of aerobic ammonia oxidation and anammox/denitrification would-in the absence of compensating nitrogen sources-limit surface primary productivity, especially that of large eukaryotic cells with high nutrient demands (Marañón, 2015). However, chlorophyll ${ }^{15} \mathrm{~N}$ isotope records suggest eukaryotes remained abundant. Different classes of photosynthetic organisms express diagnostic ${ }^{15} \mathrm{~N}$ fractionations between biomass and chlorophyll that are independent of their nitrogen substrate (Higgins et al., 2011). The $\delta^{15} \mathrm{~N}$ offset between bulk OM and chlorophyll-derived porphyrins preserved in sediments $\left(\varepsilon_{\text {por }}\right)$ has thus been proposed as a tracer of the primary producer community (Higgins et al., 2012, 2011). Previously, Higgins et al. (2010) showed that Ionian and Libyan Sea $\varepsilon_{\text {por }}$ values are stable near the expected eukaryotic value of $\sim 5 \%$ in both sapropel and marl sediments (events S2, S3, S4, and S5), indicating that exported chlorophyll was predominantly produced by eukaryotic algae throughout the Pleistocene. In contrast, if scarcity of fixed nitrogen had led to primary production that was dominated by free-living, diazotrophic cyanobacteria-as has been suggested for the Levantine Sea (Bale et al., 2019)-then we would 

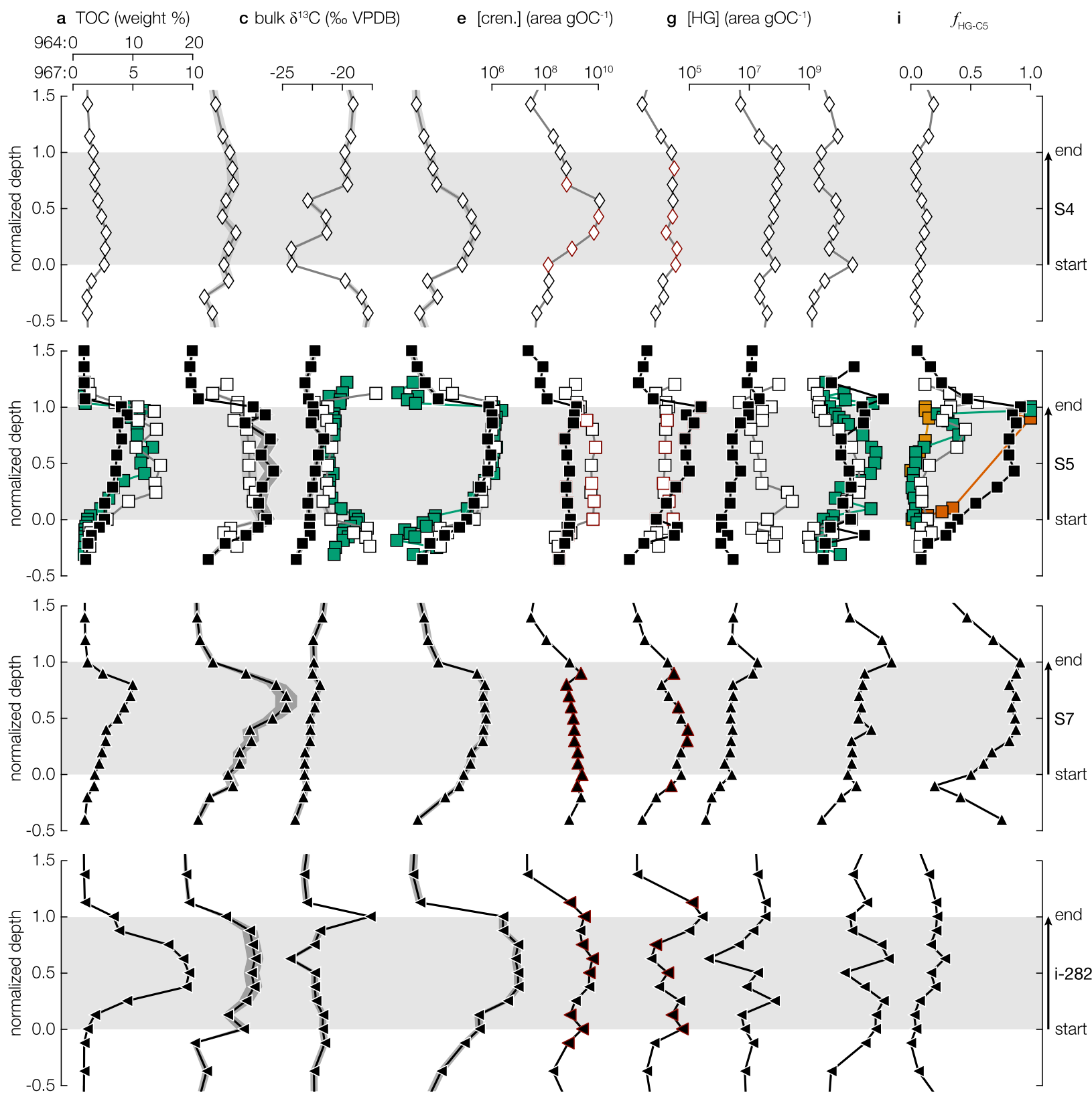

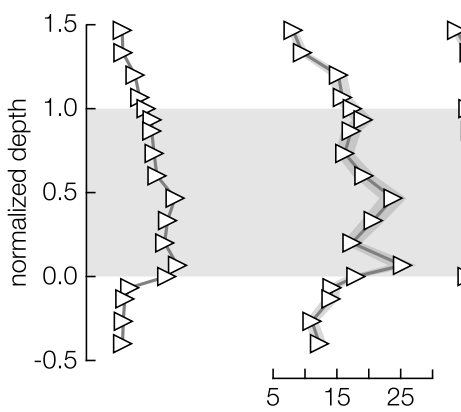

b bulkC/N $\left(\mathrm{mol} \mathrm{mol}^{-1}\right)$

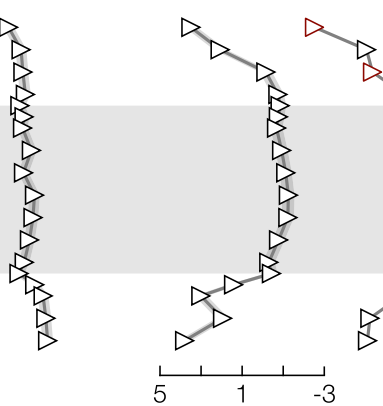

d bulk $\delta^{15} \mathrm{~N}(\%$ o AIR)

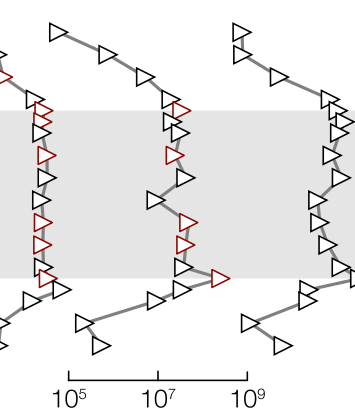

f $[\mathrm{BHT}]\left(\right.$ area $\left.\mathrm{gOC}^{-1}\right)$

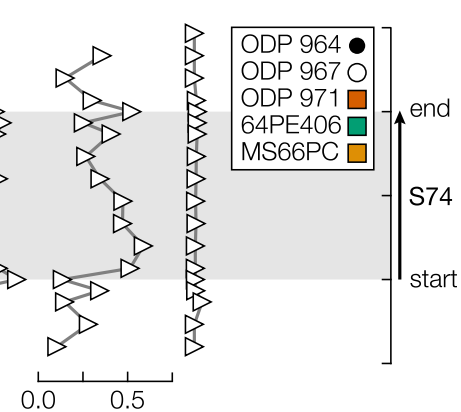

h $\quad f_{\mathrm{BHT}-\mathrm{II}}$

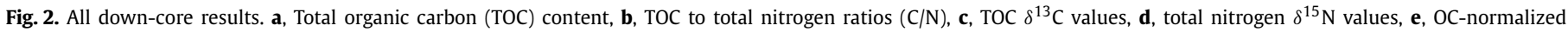

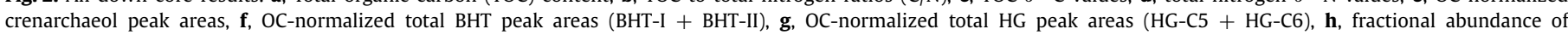

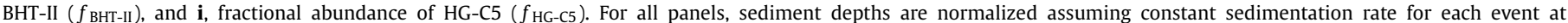

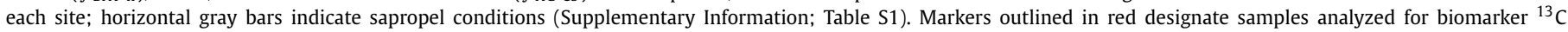

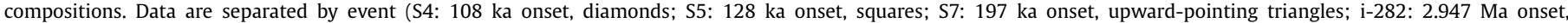

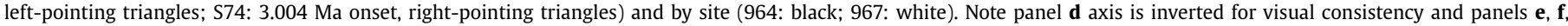

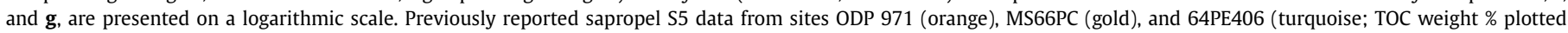

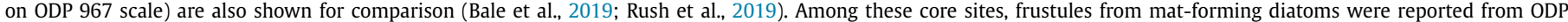
971 (Fig. 1; Table S7). Where visible, gray shaded region is analytical $\pm 1 \sigma$ uncertainty. 

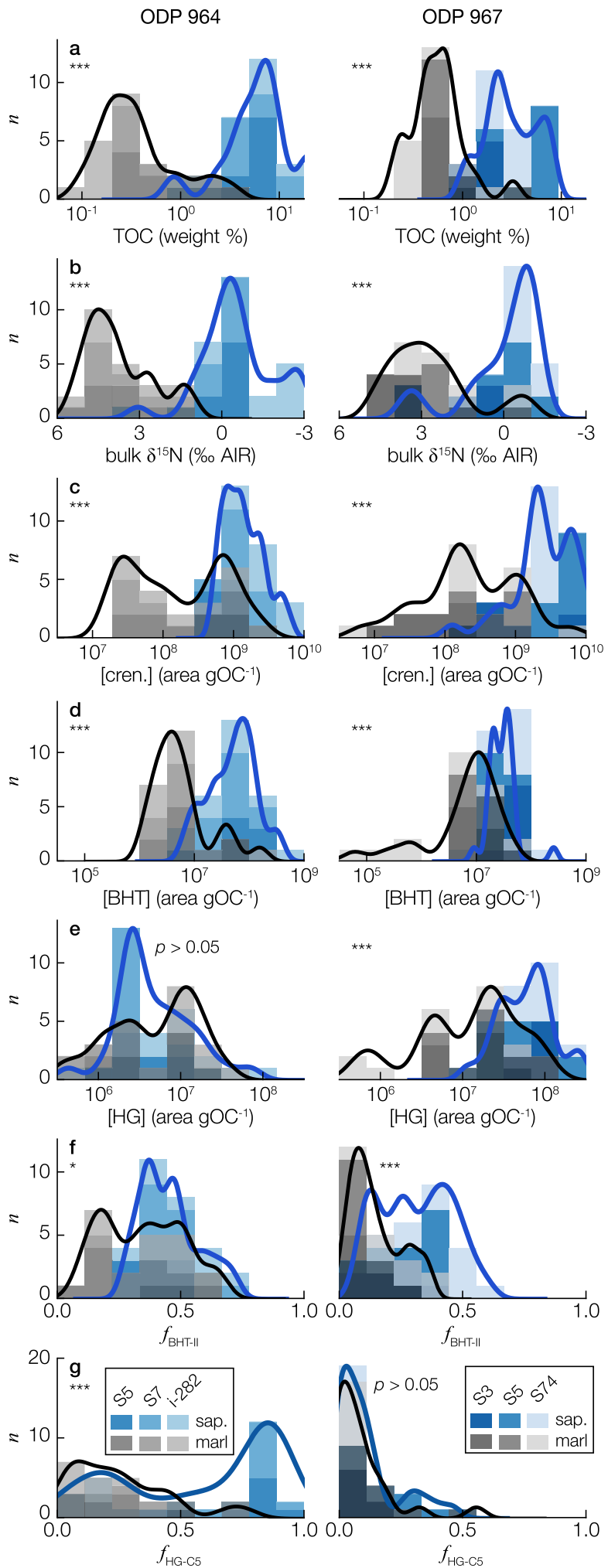

Fig. 3. Bulk and biomarker histograms. a, total organic carbon (TOC) contents, b, bulk $\delta^{15} \mathrm{~N}$ values, c, crenarchaeol peak areas, d, total BHT peak areas (BHT-I + BHT-II), e, total HG peak areas (HG- $\left.\mathrm{C}_{5}+\mathrm{HG}_{-} \mathrm{C}_{6}\right)$, f, fractional abundances of BHT-II $\left(f_{\text {BHT-II }}\right)$, and $\mathbf{g}$, fractional abundances of HG-C 5 ( $\left.f_{\text {HG-C5 }}\right)$ for ODP site 964 (left column) and ODP site 967 (right column). Data are color-coded by event (S4: $108 \mathrm{ka}$; S5: 128 ka onset; S7: 197 ka onset; i-282: 2.947 Ma onset; S74: 3.004 Ma onset) and by their position as either internal to (blues) or external to (grayscale) each sapropel. Thick blue (internal) and black (external) lines represent kernel density estimates of the total data distributions. Stars indicate that the null hypothesis of equal means for all internal and all external sample distributions is rejected at the $\left.p=0.05^{*}\right), p=0.01\left(^{* *}\right)$, or $\left.p=0.001^{* * *}\right)$ level. Note panels $\mathbf{a}, \mathbf{c}, \mathbf{d}$, and $\mathbf{e}$ are presented on a logarithmic scale and panel $\mathbf{b}$ axis is inverted for visual consistency.

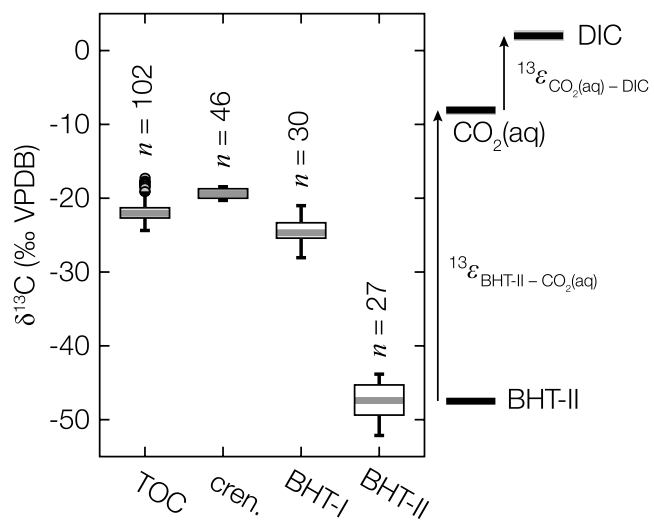

Fig. 4. All measured ${ }^{13} \mathrm{C}$ compositions. Box-and-whisker plots of all measured $\delta^{13} \mathrm{C}$ values for: total organic carbon (TOC), crenarchaeol (cren.), BHT-I, and BHT-II. Plots represent the median values (thick gray line), inter-quartile ranges (box), and 95\% confidence intervals (whiskers) for each population; outliers are shown as open circles. Also shown are predicted fractionation factors for: (i) anammox bacteria BHT-II biosynthesis relative to dissolved $\mathrm{CO}_{2}\left[\mathrm{CO}_{2}(\mathrm{aq})\right]:{ }^{13} \epsilon_{\mathrm{BHT}-\mathrm{II}-\mathrm{CO} 2(\mathrm{aq})}=39.4 \pm$ $0.6 \%$ (Schouten et al., 2004), and (ii) $\mathrm{CO}_{2}$ (aq) relative to DIC (assuming $\mathrm{T}=15^{\circ} \mathrm{C}$ ): ${ }^{13} \epsilon_{\mathrm{CO} 2(\mathrm{aq}) \text { - DIC }}=10.1 \pm 0.4 \%$. Starting from the median BHT-II $\delta^{13} \mathrm{C}$ value, this predicts DIC $\delta^{13} \mathrm{C}=2.1 \pm 0.7 \%$ VPDB (inter quartile range: 0.1 to $4.2 \%$ ), indicating that BHT-II ${ }^{13} \mathrm{C}$ composition tracks DIC ${ }^{13} \mathrm{C}$ composition.

expect $\varepsilon_{\text {por }}$ values to oscillate from $+5 \%$ during marls to $\cong 0 \% 0$ during sapropel events (Higgins et al., 2012). The stability of $\varepsilon_{\text {por }}$ at values similar to modern oligotrophic conditions prompted the proposal that primary production and OM export remained both low and eukaryotic (Higgins et al., 2011; Sachs and Repeta, 1999). Despite this consistency, there currently exists no direct evidence that OM export remained low during sapropel conditions (Rohling et al., 2015).

Alternatively, we propose that symbiosis between eukaryotic algal hosts and diazotrophic cyanobacteria leads to the simultaneous expression of diazotrophic bulk $\delta^{15} \mathrm{~N}$ values and eukaryotic $\varepsilon_{\text {por }}$ signatures. Although both partners perform photosynthesis, we predict that $\varepsilon_{\text {por }}$ of diatom-diazotroph symbioses retains a eukaryotic signature because cell volume and photosynthetic capacity of the diatom host far exceed those of the cyanobacterial symbiont (Inomura et al., 2020). Symbioses between diatoms and heterocystous cyanobacteria are commonly observed in the modern ocean, particularly in the tropics and subtropics (Follett et al., 2018; Karl et al., 2012; White et al., 2013; Yeung et al., 2012; Zehr, 2011). Here, we utilize heterocyst glycolipids (HGs)-a class of stable lipid biomarkers produced exclusively within the membrane of $\mathrm{N}_{2}$-fixing cyanobacterial heterocyst cells (Bauersachs et al., 2010)-to quantify the relative importance of $\mathrm{N}_{2}$ fixation by diatom-diazotroph symbioses vs. free-living cyanobacteria during sapropel events. Carbon-normalized total HG concentrations are relatively stable at site 964 in both sapropel and marl sediments, whereas they increase sharply within sapropels at site 967 , particularly during Pliocene event S74 (Fig. 2g, 3e, S2b). Persistently high HG abundance confirms widespread diazotrophy despite porphyrin-based evidence for predominantly eukaryotic photosynthesis (Higgins et al., 2011).

Additionally, HG molecular distributions provide taxonomic information: endosymbiotic cyanobacteria associated with mator raft-forming diatoms of the genera Rhizosolenia, Hemiaulus, and Chaetoceros exclusively produce HGs containing pentose head groups $\left(\mathrm{HG}-\mathrm{C}_{5}\right)$, whereas free-living diazotrophic cyanobacteria produce $\mathrm{HGs}$ containing hexose head groups $\left(\mathrm{HG}-\mathrm{C}_{6}\right.$ ) (Bauersachs et al., 2010; Schouten et al., 2013). Similar to previous results from event S5 in the Libyan Sea (Bale et al., 2019), our results show large increases in the fraction of endosymbiont-derived HG$\mathrm{C}_{5}$ compounds $\left[f_{\mathrm{HG}-\mathrm{C} 5}=\mathrm{HG}-\mathrm{C}_{5} /\left(\mathrm{HG}-\mathrm{C}_{5}+\mathrm{HG}-\mathrm{C}_{6}\right)\right]$ during all 

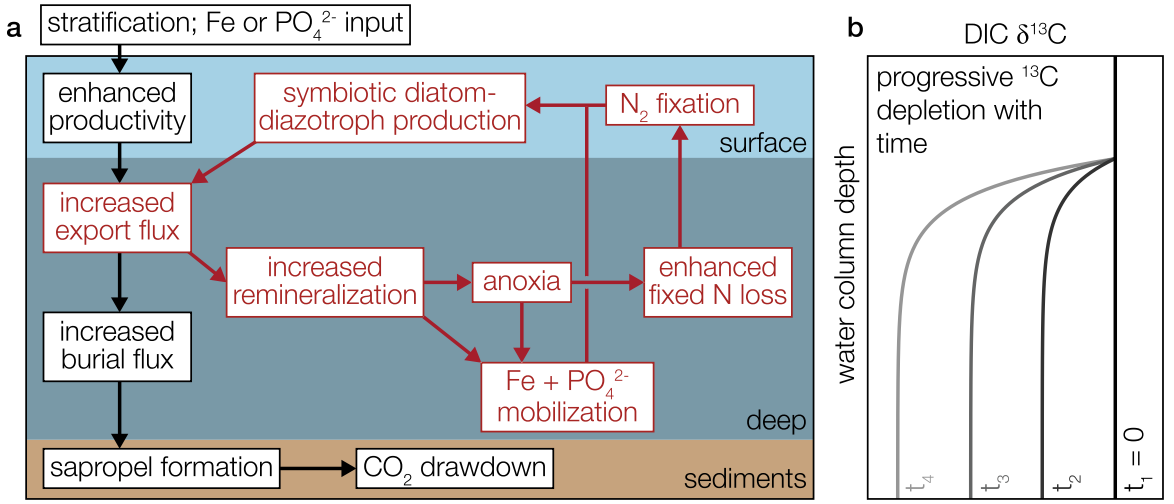

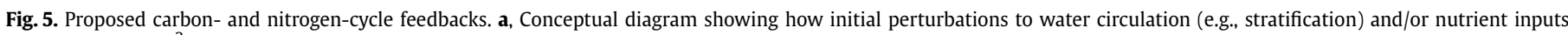

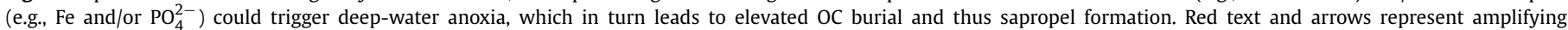

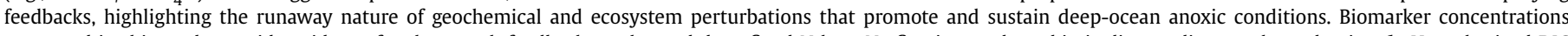

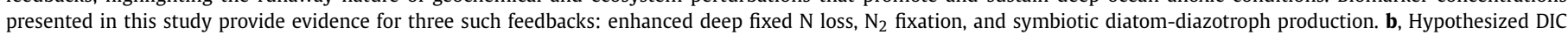

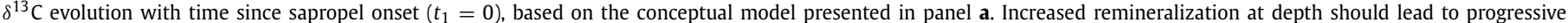
deep-water DIC ${ }^{13} \mathrm{C}$ depletion throughout a sapropel event.

sapropel events in the Ionian Sea, and particularly during Pleistocene events S5 and S7 (Fig. 2i, 3g, S3b). Thus, while total HG concentrations in the Ionian Sea sediments remained relatively stable, their molecular distributions shifted dramatically. This finding agrees with mass sedimentation of Hemiaulus, Rhizosolenia, and Chaetoceros diatom microfossils observed throughout the Ionian and Libyan Seas during sapropel S5 (Fig. 1; Table S7), previously speculated to originate from diatom-diazotroph symbioses (Kemp et al., 1999; Sachs and Repeta, 1999).

In contrast, high relative abundance of $\mathrm{HG}-\mathrm{C}_{6}$ compounds throughout the Levantine Sea documents the continuous importance of free-living heterocystous cyanobacteria during all events in this region (Fig. 2i, 3g, S3b). Such trends have previously been attributed to the formation of brackish surface waters resulting from enhanced Nile River outflow, thus favoring free-living heterocystous cyanobacteria in the Levantine Sea (Bale et al., 2019). This contrasts with the dominance of diatom-diazotroph symbioses in the Ionian and Libyan Seas, reflecting their requirement for persistent euhaline salinity. Congruent HG lipid distributions and diatom microfossils thus imply that surface water freshening to brackish levels was limited to the proximal Levantine Sea and that the gradient in surface salinity between the Levantine and Ionian Seas (Rohling et al., 2015) shaped cyanobacterial and eukaryotic algal ecology. Although HG records exhibit regional variability due to hydrologic differences between sites, our biomarker results nonetheless confirm the widespread pattern of fixed nitrogen loss throughout the deeper waters of the Eastern Mediterranean and associated diazotrophy for all studied sapropels. Critically, HG distributions additionally reveal the importance of diatom-diazotroph symbioses in locations where no diatom microfossils are preserved (i.e., site 964; Kemp et al., 1998).

Diatom-diazotroph symbiosis likely fueled elevated export production throughout much of the Eastern Mediterraneanparticularly in regions that are distal from major freshwater river inputs (Fig. 1). We hypothesize that at site 964, a combination of nitrogen limitation, relatively higher iron (Fe) and phosphate $\left(\mathrm{PO}_{4}^{2-}\right)$ nutrient concentrations from anoxic regeneration (Van Cappellen and Ingall, 1996) compared to higher terrigenous supply of nutrients at site 967, and euhaline conditions (van der Meer et al., 2007) favored symbiotic consortia over free-living, $\mathrm{N}_{2}$-fixing heterocystous cyanobacteria. Such consortia may have proliferated at the deep chlorophyll maximum, similar to the modern Eastern Mediterranean Sea (Crombet et al., 2011), where they could utilize $\mathrm{Fe}$ and $\mathrm{PO}_{4}^{2-}$ diffusing upward from deeper anoxic waters. The ability to vertically migrate, as observed for rhizosolenoid diatom mats in the modern ocean (Villareal et al., 1993), could have favored diatom-diazotroph symbioses over other primary producers. In contrast, dominance of free-living heterocystous diazotrophs at site 967 suggests either $\mathrm{Fe}$ and/or $\mathrm{PO}_{4}^{2-}$ co-limitation (Follett et al., 2018) or lower surface water salinity (Bale et al., 2019) in the Levantine Sea. Since terrigenous supply of $\mathrm{Fe}$ and $\mathrm{PO}_{4}^{2-}$ likely was high in this region, lower surface salinity may have been the major driver of diazotroph ecology. Because Rhizosolenia, Hemiaulus, and Chaetoceros diatoms form expansive mats or colonies that sink rapidly upon cell death (Follett et al., 2018; Sancetta et al., 1991), we expect increased productivity of diatom-diazotroph consortia to lead to efficient OM export from surface waters and thus increased burial flux-even under oligotrophic conditions (Karl et al., 2003). This hypothesis is supported by modern oceanographic observations, which show that seasonal diatom-diazotroph blooms drive pulses of elevated export flux (up to $3 \times$ background values) in the North Pacific Subtropical Gyre (Follett et al., 2018; Karl et al., 2012), the Amazon Plume (Yeung et al., 2012), off the Oregon coast (Sancetta et al., 1991), and in the Gulf of California (White et al., 2013). In contrast, free-living eukaryotes and cyanobacteria would exhibit slower sinking velocities, leading to more efficient recycling within the surface, less export production, smaller burial flux, and weaker deep-water deoxygenation in the Levantine Sea.

\subsection{Increased export production sustains deep-water anoxia}

Given this evidence, we propose a feedback mechanism whereby perturbations to basin circulation or initial increases in nutrient supply (i.e., $\mathrm{Fe}$ and/or $\mathrm{PO}_{4}^{2-}$ loadings) promote the proliferation of diatom-diazotroph symbiosis. This in turn leads to increased OM export, quantitative deep water $\mathrm{O}_{2}$ consumption, loss of fixed nitrogen, and new nitrogen fixation to compensate these losses, as shown schematically in Fig. 5a. The reinforcing feedback between anammox and diatom-diazotroph symbioses intensifies the Mediterranean Sea biological pump, i.e., it promotes more efficient sequestration of carbon into deep waters. Intensification of the biological pump and OM remineralization at depth should lead to accumulation of dissolved inorganic carbon (DIC) within poorly circulating, anoxic deep-water masses. Because organic carbon is depleted in ${ }^{13} \mathrm{C}$ relative to initial DIC, we predict that $\delta^{13} \mathrm{C}$ values of deep-water DIC should progressively decrease with time within each sapropel event (Fig. 5b). Unfortunately, anoxic and corrosive bottom waters dissolve carbonate and preclude the use of benthic calcifying organisms as DIC $\delta^{13} \mathrm{C}$ tracers during sapropel conditions (Grimm et al., 2015). Instead, we test this feedback hypothesis by 


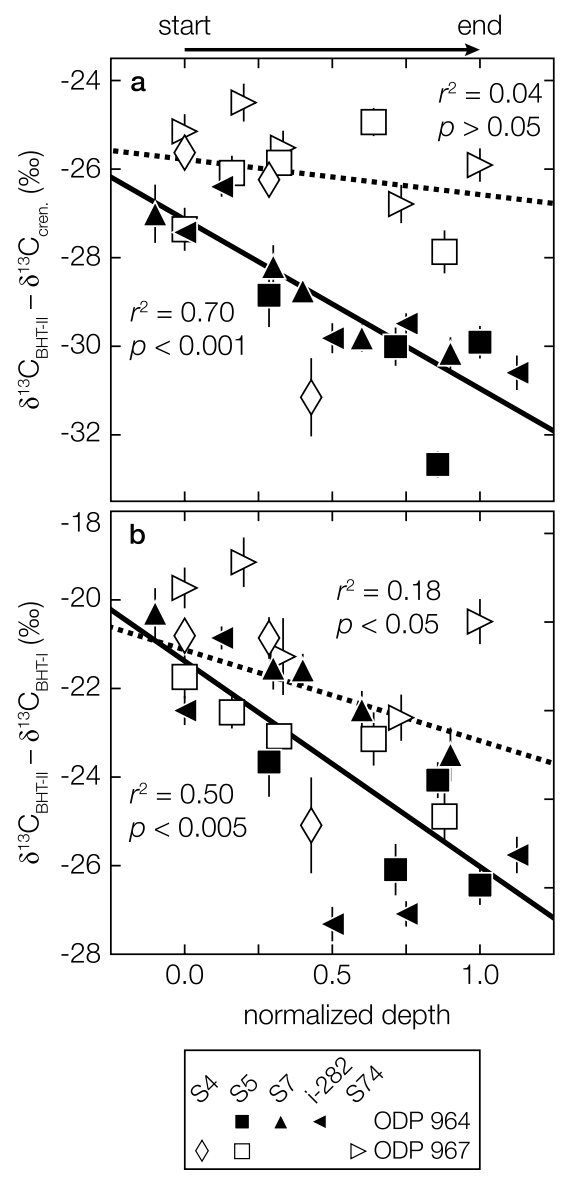

Fig. 6. Evidence for deep-water DIC accumulation during sapropels. $\delta^{13} \mathrm{C}$ offsets between a, BHT-II and crenarchaeol (produced at the base and the top of the chemocline, respectively) and b, BHT-II and BHT-I (produced at the base of the chemocline and the entire water column, respectively) as a function of normalized depth (assuming constant sedimentation rate) within each sapropel event. Data are separated by event (S4: 108 ka onset, diamonds; S5: 128 ka onset, squares; S7: 197 ka onset, upward-pointing triangles; i-282: 2.947 Ma onset, left-pointing triangles; S74: 3.004 Ma onset, right-pointing triangles) and by site (964: black; 967 : white). Solid and dotted lines are weighted least squares regressions for sites 964 and 967, respectively. BHT-II ${ }^{13} \mathrm{C}$ depletion relative to both crenarchaeol and BHTI with time-especially apparent at site 964-indicates progressive deep-ocean DIC ${ }^{13} \mathrm{C}$ depletion due to organic matter remineralization. Error bars represent propagated analytical $\pm 1 \sigma$ uncertainty.

utilizing the ${ }^{13} \mathrm{C}$ difference between BHT-II, produced by anammox bacteria in the anoxic lower chemocline (Lam et al., 2007; Rush et al., 2019), and crenarchaeol, produced by ammonia-oxidizing archaea in the suboxic upper chemocline (Lam et al., 2007; Polik et al., 2018; Wakeham et al., 2012; see Supplementary Information for further discussion) (Fig. 6a). By using the $\delta^{13} \mathrm{C}$ difference rather than relying on absolute $\delta^{13} \mathrm{C}$ values, this tracer is robust to variability in ${ }^{13} \mathrm{C}$ fractionation due to, e.g., temperature or vital effects. Observed ${ }^{13} \mathrm{C}$ differences between BHT-II and BHT-I as well as BHT-II and crenarchaeol exhibit similar slopes (site 964/967: crenarchaeol $-3.82 \pm 0.71 /-0.80 \pm 1.16$, BHT-I/II $-4.64 \pm 1.33 /-$ $2.05 \pm 1.34$; Fig. $6 \mathrm{~b}$ ), confirming the robustness of this approach.

Results show the gradient in DIC $\delta^{13} \mathrm{C}$ values across the chemocline increases linearly by up to $4 \%$ across all sapropel events at site 964, consistent with the hypothesis of continuous deep-water carbon sequestration in the Ionian Sea. An increase in foraminiferal $\delta^{13} \mathrm{C}$ depth gradients has similarly been shown at shallower-water sill sites during the Holocene S1 event (Grimm et al., 2015). The larger magnitude observed here relative to that of Grimm et al. (2015) likely reflects two fundamental differences: (i) BHT-II better tracks deep, anoxic water masses that would dissolve foraminiferal tests; and (ii) sapropel S1 was less intense than earlier events (Rohling et al., 2015). Assuming that: (i) Mediterranean DIC was identical to modern conditions at sapropel onset $(2200 \mu \mathrm{M}$ concentration, $\delta^{13} \mathrm{C}=+1 \%$; Rohling et al., 2015), (ii) the ${ }^{13} \mathrm{C}$ composition of new DIC equaled that of remineralized organic carbon (Fig. 4), and (iii) biomarker $\delta^{13} \mathrm{C}$ gradients accurately reflect changing DIC ${ }^{13} \mathrm{C}$ compositions (see Supplementary Information for a discussion of $\mathrm{CO}_{2}$-dependence of biomarker isotope effects), we estimate that $\sim 400 \mu \mathrm{M}$ DIC was cumulatively added to the deep Ionian Sea prior to sapropel termination. This observation requires that anoxia was perennial, although the vertical extent of the anoxic water mass and intensity of nitrogen cycling may have varied seasonally.

The weaker or insignificant evolution of the $\delta^{13} \mathrm{C}$ gradient at site 967 likely reflects lower abundance of diatom-diazotroph symbiotic consortia, in addition to partial mixing and reoxygenation of shallower and/or more land proximal water masses (Grimm et al., 2015). The higher relative abundances of $C_{6}$ HGs and lower TOC content at site 967 (Fig. 2a, 2i) further confirm that brackish surface water near the Nile River (Rohling et al., 2015) favored free-living heterocystous cyanobacteria (Bale et al., 2019), leading to reduced OM burial flux in the Levantine Sea as compared to the Ionian and Libyan Seas.

\subsection{Implications for ocean anoxia}

Given the general nature of the mechanism proposed here, we hypothesize that similar symbiotic dependencies may have proliferated during periods of open-ocean anoxia further back in Earth's history, e.g., Cretaceous ocean anoxic events (OAEs; 145 to 66 $\mathrm{Ma})$ or the Paleocene-Eocene Tethys Ocean ( $56 \mathrm{Ma})$. Similar to sapropels, Cretaceous OAE sediments exhibit high OC content, ${ }^{15} \mathrm{~N}$ depleted bulk OM, and $\varepsilon_{\text {por }}$ values diagnostic of eukaryotic algae (Higgins et al., 2012). These signals are all consistent with elevated eukaryote-diazotroph export production.

Several lines of evidence suggest such symbioses may have been more common during the Cretaceous and early Cenozoic than previously recognized: (i) Rhizosolenia and Hemiaulus genera survived the OAE-2 diatom extinction (Harwood et al., 2007) and radiated near 91 Ma (Sinninghe Damsté, 2004). (ii) Diatomaceous deposits have been observed in some OAE-1b black shales (Harwood and Gersonde, 1990). (iii) Similar to the modern ocean (Zehr, 2011), diazotrophs could have formed symbioses with other phytoplankton such as dinoflagellates and haptophytes. Haptophytespecific endosymbiotic diazotrophs emerged before 90 Ma (based on molecular clocks; Cornejo-Castillo et al., 2016) and potentially as early as $110 \mathrm{Ma}$ (based on the fossil record of their haptophyte host, Braarudosphaera bigelowii; Fonseca et al., 2019). We speculate that increased burial flux due to emerging algae-diazotroph symbioses could have shaped carbon and nitrogen cycle excursions over the last 100 million years.

Despite these commonalities, differences in water circulation, geography, and/or nutrient inputs between open-ocean OAEs and sapropel events of the restricted Mediterranean Sea may have shaped their respective nitrogen-cycle responses by promoting a different balance of nitrogen loss pathways. For example, high upwelling rates during OAE-2 could bring ammonia-rich deep water into closer contact with aerobic surface waters. This may favor ammonia oxidation coupled to nitrite oxidation (i.e., a relatively more oxidative fate for nitrite; Higgins et al., 2012). This idea is supported by proto-North Atlantic OAE biomarker distributions, which show a high abundance of BHP degradation products that are methylated at the C-2 position (2Me-hopanoids) (Kuypers et al., 2004). Recent experimental results have shown that these compounds are produced in abundance by nitrite oxidizing bacteria of the genus Nitrobacter (Elling et al., 2020). This scenario is also con- 
sistent with model predictions and data compilations for upwelling regions during OAE-2, in which all components of the nitrogen cycle are greatly amplified in response to higher simulated phosphorous inputs (Naafs et al., 2019).

By contrast, a sapropel-like scenario would amplify the more strongly reducing pathway of nitrite reduction via anammox, leading to an abundance of BHT-II and suppression of 2Me-hopanoid deposition. This is supported by the fact that 2Me-hopanoids were not detected in the sapropel samples studied here and have been reported only in very low concentrations for other sapropel events (Löhr et al., 2018). Importantly, regardless of whether anammox or heterotrophic denitrification consumes fixed nitrogen, diazotrophy-including algae-diazotroph symbioses-would still proliferate under either scenario.

Such scenarios imply that differences in circulation, combined with nutrient loading, impact the intensity and duration of diatom-diazotroph export production and corresponding deepwater anoxia. For Mediterranean sapropels, climatically induced changes in circulation and water column structure triggered deepwater reoxygenation (Rohling et al., 2015), thus reducing nitrogen stress and decreasing phosphorous regeneration, terminating the intensified biological pump, and returning the system to lowexport oligotrophic conditions. For open-ocean Cretaceous OAEs, either (i) prolonged atmospheric $\mathrm{O}_{2}$ accumulation and water column reoxygenation (Van Cappellen and Ingall, 1996) or (ii) limitation of nutrients such as molybdenum and silica that are essential for diazotrophy (Goldberg et al., 2016) and diatom growth (Krause et al., 2019; Martin-Jézéquel et al., 2000), respectively, could have terminated this mechanism over longer (>500 ka) timescales.

\section{Conclusions}

The links between deep-water oxygen content, nutrient cycling, and microbial ecology are critically important for understanding the triggers of-and responses to-marine anoxia, both in the geologic past and due to ongoing anthropogenic perturbations. Our study highlights the power of simultaneously investigating a broad suite of organic biomarkers-including their stable isotope compositions-to understand how the nitrogen cycle drives and responds to anoxia throughout Earth's history. The data specifically illuminate the role of anammox as a sink for nitrite in stratified, basinal systems, and show this loss of fixed nitrogen favors the proliferation of ecosystems that can both migrate vertically and harbor endosymbiotic diazotrophs. We further show how gradients in Mediterranean hydrography during sapropel events controlled diazotroph ecology, favoring endosymbiotic diazotrophs in euhaline waters of the Ionian and Libyan Seas and free-living diazotrophs in the Levantine Sea, and that this gradient in turn impacted organic matter burial flux. Although all sapropels share common geochemical signatures, variations in organic matter content independent of biomarker records suggest varying contributions of different primary producers between sapropel events. Further studies using additional biomarkers are needed to provide supporting evidence for the occurrence of diatoms at sites without preserved frustules and to assess the roles of different primary producers. Our results constitute the first spatiotemporally resolved, simultaneous assessment of fixed nitrogen sources and sinks during episodic Eastern Mediterranean anoxic events, and they indicate that the nutrient regime likely resembled that of modern anoxic closed basins such as the Black Sea. Although Mediterranean sapropel events differ in their extent, duration, and oceanographic conditions from earlier anoxic events such as Mesozoic OAEs, the emergence of diazotroph-algae symbioses during the Mesozoic suggests that similar feedbacks could have driven enhanced organic carbon burial flux in the distant geologic past.

\section{CRediT authorship contribution statement}

F.J.E., J.D.H., and A.P. conceived the study; F.J.E., J.D.H., J.J.K., K.W.B., and C.A.P. performed laboratory procedures and data analysis; F.J.E., J.D.H., and A.P. wrote the manuscript with contributions from all authors.

\section{Declaration of competing interest}

The authors declare that they have no known competing financial interests or personal relationships that could have appeared to influence the work reported in this paper.

\section{Acknowledgements}

This research used samples provided by the Ocean Drilling Program (ODP). Claire Jasper, Samuel McNichol, and Susan J. Carter are thanked for assistance with sample preparation and instrumental analyses. Benjamin A. S. Van Mooy is thanked for access to HPLC-ESI-MS. Arndt Schimmelmann is thanked for the $n-C_{38}$ alkane standard reference material. This work was funded through the Gordon and Betty Moore Foundation and US National Science Foundation grants 1843285,1702262 and 1349126 (to A.P.). Additional financial support was provided by the Postdoctoral Program at the Woods Hole Oceanographic Institution and U.S. Geological Survey (K.W.B.). We thank the associate editor, one anonymous reviewer, and Benjamin Uveges for constructive comments that improved this manuscript.

\section{Appendix A. Supplementary material}

Supplementary material related to this article can be found online at https://doi.org/10.1016/j.epsl.2021.117110.

\section{References}

Bale, N.J., Hennekam, R., Hopmans, E.C., Dorhout, D., Reichart, G.-J., van der Meer, M., Villareal, T.A., Damsté, J.S.S., Schouten, S., 2019. Biomarker evidence for nitrogen-fixing cyanobacterial blooms in a brackish surface layer in the Nile River plume during sapropel deposition. Geology 47, 1088-1092. https://doi.org/ 10.1130/G46682.1.

Bauersachs, T., Speelman, E.N., Hopmans, E.C., Reichart, G.-J., Schouten, S., Sinninghe Damsté, J.S., 2010. Fossilized glycolipids reveal past oceanic $\mathrm{N}_{2}$ fixation by heterocystous cyanobacteria. Proc. Natl. Acad. Sci. USA 107, 19190-19194. https:// doi.org/10.1073/pnas.1007526107.

Calvert, S.E., Nielsen, B., Fontugne, M.R., 1992. Evidence from nitrogen isotope ratios for enhanced productivity during formation of Eastern Mediterranean sapropels. Nature 359, 223. https://doi.org/10.1038/359223A0.

Collins, J.R., Edwards, B.R., Fredricks, H.F., Van Mooy, B.A.S., 2016. LOBSTAHS: an adduct-based lipidomics strategy for discovery and identification of oxidative stress biomarkers. Anal. Chem. 88, 7154-7162. https://doi.org/10.1021/acs. analchem.6b01260.

Cornejo-Castillo, F.M., Cabello, A.M., Salazar, G., Sánchez-Baracaldo, P., Lima-Mendez, G., Hingamp, P., Alberti, A., Sunagawa, S., Bork, P., de Vargas, C., Raes, J., Bowler, C., Wincker, P., Zehr, J.P., Gasol, J.M., Massana, R., Acinas, S.G., 2016. Cyanobacterial symbionts diverged in the late Cretaceous towards lineage-specific nitrogen fixation factories in single-celled phytoplankton. Nat. Commun. 7, 11071. https:// doi.org/10.1038/ncomms11071.

Crombet, Y., Leblanc, K., Quéguiner, B., Moutin, T., Rimmelin, P., Ras, J., Claustre, H., Leblond, N., Oriol, L., Pujo-Pay, M., 2011. Deep silicon maxima in the stratified oligotrophic Mediterranean Sea. Biogeosciences 8, 459-475. https://doi.org/10. 5194/bg-8-459-2011.

Elling, F.J., Hemingway, J.D., Evans, T.W., Kharbush, J.J., Spieck, E., Summons, R.E., Pearson, A., 2020. Vitamin $B_{12}$-dependent biosynthesis ties amplified 2-methylhopanoid production during oceanic anoxic events to nitrification. Proc. Natl. Acad. Sci. USA 117 (52), 32996-33004. https://doi.org/10.1073/pnas. 2012357117.

Follett, C.L., Dutkiewicz, S., Karl, D.M., Inomura, K., Follows, M.J., 2018. Seasonal resource conditions favor a summertime increase in North Pacific diatomdiazotroph associations. ISME J. 12, 1543-1557. https://doi.org/10.1038/s41396017-0012-X. 
Fonseca, M. de L., Scotese, C.R., Cachão, M., 2019. Late Cretaceous paleobiogeography of Braarudosphaera bigelowii. Mar. Micropaleontol. 152, 101738. https://doi.org/ 10.1016/j.marmicro.2019.03.010.

Goldberg, T., Poulton, S.W., Wagner, T., Kolonic, S.F., Rehkämper, M., 2016. Molybdenum drawdown during Cretaceous Oceanic Anoxic Event 2. Earth Planet. Sci. Lett. 440, 81-91. https://doi.org/10.1016/j.epsl.2016.02.006.

Grimm, R., Maier-Reimer, E., Mikolajewicz, U., Schmiedl, G., Müller-Navarra, K., Adloff, F., Grant, K.M., Ziegler, M., Lourens, L.J., Emeis, K.-C., 2015. Late glacial initiation of Holocene Eastern Mediterranean sapropel formation. Nat. Commun. 6, 7099. https://doi.org/10.1038/ncomms8099.

Harwood, D.M., Gersonde, R., 1990. Lower Cretaceous diatoms from ODP leg 113 site 693 (Weddell Sea). Part 2: resting spores, chrysophycean cysts, an endoskeletal dinoflagellate, and notes on the origin of diatoms. In: Barker, P.F., Kennett, J.P. (Eds.), Proceedings of the Ocean Drilling Program, 113 Scientific Results. Ocean Drilling Program, p. 23

Harwood, D.M., Nikolaev, V.A., Winter, D.M., 2007. Cretaceous records of diatom evolution, radiation, and expansion. Paleontol. Soc. Pap. 13, 33-59. https:// doi.org/10.1017/S1089332600001455.

Hemingway, J.D., Kusch, S., Shah Walter, S.R., Polik, C.A., Elling, F.J., Pearson, A., 2018. A novel method to measure the ${ }^{13} \mathrm{C}$ composition of intact bacteriohopanepolyols. Org. Geochem. 123, 144-147. https://doi.org/10.1016/j.orggeochem.2018.07. 002.

Higgins, M.B., Robinson, R.S., Carter, S.J., Pearson, A., 2010. Evidence from chlorin nitrogen isotopes for alternating nutrient regimes in the Eastern Mediterranean Sea. Earth Planet. Sci. Lett. 290, 102-107. https://doi.org/10.1016/j.epsl.2009.12. 009.

Higgins, M.B., Robinson, R.S., Husson, J.M., Carter, S.J., Pearson, A., 2012. Dominant eukaryotic export production during ocean anoxic events reflects the importance of recycled $\mathrm{NH}_{4}^{+}$. Proc. Natl. Acad. Sci. USA 109, 2269-2274

Higgins, M.B., Wolfe-Simon, F., Robinson, R.S., Qin, Y., Saito, M.A., Pearson, A., 2011. Paleoenvironmental implications of taxonomic variation among $\delta^{15} \mathrm{~N}$ values of chloropigments. Geochim. Cosmochim. Acta 75, 7351-7363. https://doi.org/10. 1016/j.gca.2011.04.024.

Inomura, K., Follett, C.L., Masuda, T., Eichner, M., Prášil, O., Deutsch, C., 2020. Carbon transfer from the host diatom enables fast growth and high rate of $\mathrm{N}_{2}$ fixation by symbiotic heterocystous cyanobacteria. Plants 9, 192. https://doi.org/10.3390/ plants9020192.

Karl, D.M., Bates, N.R., Emerson, S., Harrison, P.J., Jeandel, C., Llinâs, O., Liu, K.-K., Marty, J.-C., Michaels, A.F., Miquel, J.C., Neuer, S., Nojiri, Y., Wong, C.S., 2003. Temporal studies of biogeochemical processes determined from ocean timeseries observations during the JGOFS era. In: Fasham, M.J.R. (Ed.), Ocean Biogeochemistry: the Role of the Ocean Carbon Cycle in Global Change, Global Change - the IGBP Series (Closed). Springer, Berlin, Heidelberg, pp. 239-267.

Karl, D.M., Church, M.J., Dore, J.E., Letelier, R.M., Mahaffey, C., 2012. Predictable and efficient carbon sequestration in the North Pacific Ocean supported by symbiotic nitrogen fixation. Proc. Natl. Acad. Sci. USA 109, 1842-1849. https://doi.org/10. 1073/pnas.1120312109.

Kemp, A.E.S., Pearce, R.B., Koizumi, I., Pike, J., Rance, S.J., 1999. The role of matforming diatoms in the formation of Mediterranean sapropels. Nature 398, 57-61. https://doi.org/10.1038/18001.

Kemp, A.E.S., Pearce, R.B., Pike, J., Marshall, J.E.A., 1998. Microfabric and microcompositional studies of Pliocene and quaternary sapropels from the Eastern Mediterranean. In: Robertson, A.H.F., Emeis, K.-C., Richter, C., Camerlenghi, A. (Eds.), Proceedings of the Ocean Drilling Program, 160 Scientific Results. Ocean Drilling Program. College Station, TX

Kemp, A.E.S., Villareal, T.A., 2013. High diatom production and export in stratified waters - a potential negative feedback to global warming. Prog. Oceanogr. 119, 4-23. https://doi.org/10.1016/j.pocean.2013.06.004.

Krause, J.W., Schulz, I.K., Rowe, K.A., Dobbins, W., Winding, M.H.S., Sejr, M.K., Duarte, C.M., Agustí, S., 2019. Silicic acid limitation drives bloom termination and potential carbon sequestration in an Arctic bloom. Sci. Rep. 9, 8149. https:// doi.org/10.1038/s41598-019-44587-4.

Kusch, S., Shah Walter, S.R., Hemingway, J.D., Pearson, A., 2018. Improved chromatography reveals multiple new bacteriohopanepolyol isomers in marine sediments. Org. Geochem. 124, 12-21. https://doi.org/10.1016/j.orggeochem.2018.07. 010.

Kuypers, M.M.M., van Breugel, Y., Schouten, S., Erba, E., Sinninghe Damsté, J.S., 2004. $\mathrm{N}_{2}$-fixing cyanobacteria supplied nutrient $\mathrm{N}$ for Cretaceous oceanic anoxic events. Geology 32, 853. https://doi.org/10.1130/G20458.1.

Lam, P., Jensen, M.M., Lavik, G., McGinnis, D.F., Muller, B., Schubert, C.J., Amann, R., Thamdrup, B., Kuypers, M.M.M., 2007. Linking crenarchaeal and bacterial nitrification to anammox in the Black Sea. Proc. Natl. Acad. Sci. USA 104, 7104-7109. https://doi.org/10.1073/pnas.0611081104.

Löhr, S.C., Kennedy, M.J., George, S.C., Williamson, R.J., Xu, H., 2018. Sediment microfabric records mass sedimentation of colonial cyanobacteria and extensive syndepositional metazoan reworking in Pliocene sapropels. Depos. Rec. 4, 293-317. https://doi.org/10.1002/dep2.49.

Marañón, E., 2015. Cell size as a key determinant of phytoplankton metabolism and community structure. Annu. Rev. Mar. Sci. 7, 241-264. https://doi.org/10.1146/ annurev-marine-010814-015955.
Martin-Jézéquel, V., Hildebrand, M., Brzezinski, M.A., 2000. Silicon metabolism in diatoms: implications for growth. J. Phycol. 36, 821-840. https://doi.org/10.1046 j.1529-8817.2000.00019.x.

Mills, M.M., Arrigo, K.R., 2010. Magnitude of oceanic nitrogen fixation influenced by the nutrient uptake ratio of phytoplankton. Nat. Geosci. 3, 412-416. https:// doi.org/10.1038/ngeo856.

Möbius, J., Lahajnar, N., Emeis, K.-C., 2010. Diagenetic control of nitrogen isotope ratios in Holocene sapropels and recent sediments from the Eastern Mediterranean Sea. Biogeosciences 7, 3901-3914. https://doi.org/10.5194/bg-7-39012010.

Mook, W.G., Bommerson, J.C., Staverman, W.H., 1974. Carbon isotope fractionation between dissolved bicarbonate and gaseous carbon dioxide. Earth Planet. Sci. Lett. 22, 169-176. https://doi.org/10.1016/0012-821X(74)90078-8.

Naafs, B.D.A., Monteiro, F.M., Pearson, A., Higgins, M.B., Pancost, R.D., Ridgwell, A. 2019. Fundamentally different global marine nitrogen cycling in response to severe ocean deoxygenation. Proc. Natl. Acad. Sci. USA 116, 24979-24984. https:// doi.org/10.1073/pnas.1905553116.

Pearson, A., Hurley, S.J., Walter, S.R.S., Kusch, S., Lichtin, S., Zhang, Y.G., 2016. Stable carbon isotope ratios of intact GDGTs indicate heterogeneous sources to marine sediments. Geochim. Cosmochim. Acta 181, 18-35. https://doi.org/10.1016/j.gca. 2016.02.034.

Polik, C.A., Elling, F.J., Pearson, A., 2018. Impacts of paleoecology on the TEX $_{86}$ sea surface temperature proxy in the Pliocene-Pleistocene Mediterranean Sea. Paleoceanogr. Paleoclimatol. 33, 1472-1489. https://doi.org/10.1029/2018PA003494.

Rohling, E.J., Marino, G., Grant, K.M., 2015. Mediterranean climate and oceanography, and the periodic development of anoxic events (sapropels). Earth-Sci. Rev. 143, 62-97. https://doi.org/10.1016/j.earscirev.2015.01.008.

Rush, D., Sinninghe Damsté, J.S., Poulton, S.W., Thamdrup, B., Garside, A.L. Acuña González, J., Schouten, S., Jetten, M.S.M., Talbot, H.M., 2014. Anaerobic ammonium-oxidising bacteria: a biological source of the bacteriohopanetetrol stereoisomer in marine sediments. Geochim. Cosmochim. Acta 140, 50-64. https://doi.org/10.1016/j.gca.2014.05.014.

Rush, D., Talbot, H.M., van der Meer, M.T.J., Hopmans, E.C., Douglas, B., Sinninghe Damsté, J.S., 2019. Biomarker evidence for the occurrence of anaerobic ammonium oxidation in the Eastern Mediterranean Sea during quaternary and Pliocene sapropel formation. Biogeosciences 16, 2467-2479. https://doi.org/10. 5194/bg-16-2467-2019.

Sachs, J.P., Repeta, D.J., 1999. Oligotrophy and nitrogen fixation during Eastern Mediterranean sapropel events. Science 286, 2485-2488. https://doi.org/10. 1126/science.286.5449.2485.

Sancetta, C., Villareal, T., Falkowski, P., 1991. Massive fluxes of rhizosolenid diatoms: a common occurrence? Limnol. Oceanogr. 36, 1452-1457. https://doi.org/10. 4319/10.1991.36.7.1452.

Schouten, S., Strous, M., Kuypers, M.M.M., Rijpstra, W.I.C., Baas, M., Schubert, C.J., Jetten, M.S.M., Sinninghe Damsté, J.S., 2004. Stable carbon isotopic fractionations associated with inorganic carbon fixation by anaerobic ammonium-oxidizing bacteria. Appl. Environ. Microbiol. 70, 3785-3788. https://doi.org/10.1128/AEM. 70.6.3785-3788.2004.

Schouten, S., Villareal, T.A., Hopmans, E.C., Mets, A., Swanson, K.M., Sinninghe Damsté, J.S., 2013. Endosymbiotic heterocystous cyanobacteria synthesize different heterocyst glycolipids than free-living heterocystous cyanobacteria. Phytochemistry 85, 115-121. https://doi.org/10.1016/j.phytochem.2012.09.002.

Schrader, H., Matherne, A., 1981. Sapropel formation in the Eastern Mediterranean Sea: evidence from preserved opal assemblages. Micropaleontology 27, 191-203. https://doi.org/10.2307/1485285.

Sinninghe Damsté, J.S., 2004. The rise of the Rhizosolenid diatoms. Science 304 584-587. https://doi.org/10.1126/science.1096806.

Sturt, H.F., Summons, R.E., Smith, K., Elvert, M., Hinrichs, K.-U., 2004. Intact polar membrane lipids in prokaryotes and sediments deciphered by high-performance liquid chromatography/electrospray ionization multistage mass spectrometrynew biomarkers for biogeochemistry and microbial ecology. Rapid Commun. Mass Spectrom. 18, 617-628. https://doi.org/10.1002/rcm.1378.

Van Cappellen, P., Ingall, E.D., 1996. Redox stabilization of the atmosphere and oceans by phosphorus-limited marine productivity. Science 271, 493-496. https://doi.org/10.1126/science.271.5248.493.

van der Meer, M.T.J., Baas, M., Rijpstra, W.I.C., Marino, G., Rohling, E.J., Sinninghe Damsté, J.S., Schouten, S., 2007. Hydrogen isotopic compositions of long-chain alkenones record freshwater flooding of the Eastern Mediterranean at the onset of sapropel deposition. Earth Planet. Sci. Lett. 262, 594-600. https://doi.org/10. 1016/j.epsl.2007.08.014.

Villareal, T.A., Altabet, M.A., Culver-Rymsza, K., 1993. Nitrogen transport by vertically migrating diatom mats in the North Pacific Ocean. Nature 363, 709-712. https:/ doi.org/10.1038/363709a0.

Wakeham, S.G., Turich, C., Schubotz, F., Podlaska, A., Li, X.N., Varela, R., Astor, Y. Sáenz, J.P., Rush, D., Sinninghe Damsté, J.S., Summons, R.E., Scranton, M.I., Taylor, G.T., Hinrichs, K.-U., 2012. Biomarkers, chemistry and microbiology show chemoautotrophy in a multilayer chemocline in the Cariaco Basin. Deep-Sea Res., Part 1, Oceanogr. Res. Pap. 63, 133-156. https://doi.org/10.1016/j.dsr.2012. 01.005.

White, A.E., Foster, R.A., Benitez-Nelson, C.R., Masqué, P., Verdeny, E., Popp, B.N., Arthur, K.E., Prahl, F.G., 2013. Nitrogen fixation in the Gulf of California and 
the Eastern Tropical North Pacific. Prog. Oceanogr. 109, 1-17. https://doi.org/10. 1016/j.pocean.2012.09.002.

Wörmer, L., Cirés, S., Velázquez, D., Quesada, A., Hinrichs, K.-U., 2012. Cyanobacterial heterocyst glycolipids in cultures and environmental samples: diversity and biomarker potential. Limnol. Oceanogr. 57, 1775-1788. https://doi.org/10.4319/ lo.2012.57.6.1775.

Wright, J.J., Konwar, K.M., Hallam, S.J., 2012. Microbial ecology of expanding oxygen minimum zones. Nat. Rev. Microbiol. 10, 381-394. https://doi.org/10.1038/ nrmicro2778.
Yeung, L.Y., Berelson, W.M., Young, E.D., Prokopenko, M.G., Rollins, N., Coles, V.J., Montoya, J.P., Carpenter, E.J., Steinberg, D.K., Foster, R.A., Capone, D.G., Yager, P.L., 2012. Impact of diatom-diazotroph associations on carbon export in the Amazon River plume. Geophys. Res. Lett. 39, L18609. https://doi.org/10.1029/ 2012 GL053356.

Zehr, J.P., 2011. Nitrogen fixation by marine cyanobacteria. Trends Microbiol. 19, 162-173. https://doi.org/10.1016/j.tim.2010.12.004. 